Jasmina Markič

\title{
Antonio Pamies, Dmitrij Dobrovol'skij: Linguo-Cultural Competence and Phraseological Motivation
}

\author{
Baltmannsweiler: Schneider Verlag Hohengehren GmbH, 2011, 403 strani
}

Nemška založba Schneider Verlag Hohengehren GmbH je v 27. zvezku zbirke Phraseologie und Parömiologie izdala monografijo Linguo-Cultural Competence and Phraseological Motivation. Uredila sta jo avtorja številnih študij in knjig o opisni in kontrastivni frazeologiji, Antonio Pamies Bertrán z Univerze v Granadi in Dmitrij Dobrovol'skij z Ruske akademije znanosti v Moskvi. Pričujoče delo obravnava tematiko povezav med kulturo in jezikom, konkretneje, jezikovno-kulturne kompetence in frazeološke motivacije. Novejše raziskave o figurativnem jeziku, še posebej na frazeološki ravni, odpirajo nove in obširne možnosti za raziskovanje kognitivnih mrež in na njih temelječih metafor ter stalnih besednih zvez. Sodobne študije o frazeologiji se ukvarjajo $\mathrm{z}$ vprašanjem metafore in frazemov, povezanih s kulturo, ter tako s svojega zornega kota osvetljujejo večno razpravo o tem, kako sta kultura in jezik medsebojno povezana.

Knjiga ima 403 strani in je razdeljena na 39 poglavij različnih avtorjev, napisanih v francoskem, španskem, angleškem in nemškem jeziku, ki se tematsko dotikajo teme v naslovu monografije. Uvodno študijo »Cross-linguistic equivalence of idioms: does it really exist? « je prispeval Dmitrij Dobrovol'skij. V njej postavlja provokativno vprašanje, na katero ne more dati točnega odgovora, in sicer ali medjezikovna ekvivalenca pri frazemih dejansko obstaja. Če so medjezikovni ekvivalenti pojmovani le kot podobni frazemi v jeziku 1 in v jeziku 2 (tradicionalno imenovani pravi ekvivalenti), ki se uporabljajo v podobnih situacijah, je odgovor nikalen. Tovrstni ekvivalenti so tako redki, da jih lahko imamo le za izjeme. Če pa je medjezikovna ekvivalenca pojmovana na manj rigiden način, potem imamo dva načina, da odkrijemo frazeme v različnih jezikih, za katere lahko trdimo, da so ekvivalentni. Prva možnost je, da proučimo prevode frazemov v besedilih, npr. s paralelnimi korpusi. Drugi način pa je, da primerjamo frazeološke sisteme jezikov, ki jih proučujemo. $\mathrm{V}$ obeh primerih lahko odkrijemo ekvivalente, ki pa niso pravi, temveč približni. Avtor poudarja, da bi bila praktično usmerjena raziskovanja funkcionalne ekvivalence na področju raziskovanja frazeologije zelo zaželena. Funkcionalne ekvivalente, ki bi jih moral vsebovati idealen 
dvojezični frazeološki slovar, avtor razume kot ustreznice, ki se lahko uporabljajo v isti konkretni situaciji brez pomensko-komunikativne izgube. Takšne raziskave, meni Dobrovol'skij, bodo izredno koristne za leksikografsko delo, poučevanje tujega jezika in prevajalce.

O frazeološki motivaciji pišeta Antonio Pamies in Elizabeth Piirainen, o nevrolingvističnem pristopu $\mathrm{v}$ frazeologiji pa razpravlja Angel López García $\mathrm{v}$ članku »Neurolinguistics of the Lexicon-Syntax Interface«. Antonio Pamies v svojem prispevku »A propos de la motivation phraséologique« razmišlja o metaforični motivaciji, ki temelji na naši zmožnosti asociirati ideje, kar se še posebej močno kaže na področju frazeologije. Na psiholingvističnih in semantičnih asociacijah temeljijo različni pogledi na svet, ki prek jezika vplivajo na kolektivno zavest govorečih. Piirainen (»Idiom motivation from cultural perspectives: metaphors, symbols, intertextuality«) pri raziskavah frazemov povezuje dva ključna pojma: motivacijo in kulturo. Navaja dve vrsti semantičnih motivacij, metaforično in motivacijo, temelječo na simbolih. Na obe vrsti lahko dodatno vpliva intertekstualnost, ki ni povsem semantične narave, je pa izredno pomembna, saj je pri jezikih z literarno tradicijo na tisoče frazemov, ki izvirajo iz določenih besedil (Biblija, antična literarna dela, ljudske povesti ter celo filmi, oglasi in druga sodobna besedila).

Več poglavij je posvečenih kontrastivni frazeološki analizi. Tako npr. Nana Stambolishvili primerja gruzijsko in nemško frazeologijo ter meni, da so frazemi odraz duha nekega naroda in njegove svobode, hkrati pa tudi odsev univerzalnosti. Joanna Szerszunowicz razmišlja o izvoru in klasifikaciji osebnih imen kot komponent $\mathrm{v}$ poljskih, angleških in italijanskih frazemih, v drugem prispevku pa o prevajanju winged words (epea pteroenta) v govorih Lecha Walese. Natalia Med išče mehanizme za vzpostavitev semantičnega vrednotenja $\mathrm{v}$ frazeologiji romanskih jezikov. Irina V. Zykova ponuja dve metodi za raziskovanje frazemov različnih jezikov, ki naj bi osvetlili način, kako je pogled na svet s kulturne perspektive vkomponiran in shranjen za nedoločen čas v različnih nacionalnih frazeologijah. Rosa Piñel primerja podobo hudiča v nemški in španski frazeologiji. Anna Zholobova piše o frazeoloških biblizmih $\mathrm{v}$ ruščini in španščini. Tudi Teodora Kyryakova-Dinieva se posveča biblijskim frazemom, in sicer v nemščini in bolgarščini. M. Mokienko pa opisuje Slovar ruskih biblizmov in Nemško-ruski slovar biblizmov.

Ilaria Meloni razmišlja o posebnih frazemih, kinegramih, kjer sta dobesedni in frazeološki pomen metonimično prisotna drug ob drugem, ter primerja nemške in italijanske kinegrame. Alexandra Stavtseva primerja angleške in nemške frazeme, ki označujejo človeške intelektualne sposobnosti. José Alejandro Calero se posveča družbeno nekorektnim ilokutivnim govornim dejanjem in analizira metafore prevare, 
prepričevanja, izdaje, karanja in obrekovanja $\mathrm{v}$ češčini in španščini. O semantičnih in pragmatičnih vrednostih frazeoloških enot s frazemsko komponento glagola callar (molčati) v nemščini in španščini razpravlja Carmen Mellado. Anda Radulescu se osredotoča na težave pri prevajanju paremij iz romunščine v francoščino. O kontrastivni živalski frazeologiji v angleščini in bolgarščini piše Rayna Holandi, v francoščini in gruzijščini pa Natalia Sourgouladze, medtem ko Josefina Velasco Menéndez proučuje komponento svinja v ruskih in španskih frazemih. Sabine Geck predlaga kognitivno pragmatični pristop $\mathrm{k}$ analizi posebnih stalnih besednih zvez, imenovanih situationbound utterances, $\mathrm{v}$ nemščini in španščini. Lucía Luque Nadal preučuje frazeme in kultureme, ki izvirajo iz zgodovine ter pogosto presegajo meje jezika in kulture, kjer so nastali, ter prehajajo v druge jezike. Na temelju teh dognanj avtorica analizira kulturem in frazem »Potemkinova vas«.

S somatskimi frazeološkimi enotami v ukrajinščini in angleščini, njihovimi podobnostmi in razlikami na področju medosebnih odnosov (spori, odvisnost, obrekovanja) se ukvarja Irina Skrypnik. Prispevek Erike Kržišnik in Jasmine Markič $\mathrm{z}$ Univerze $\mathrm{v}$ Ljubljani obravnava pomensko participacijo frazemske komponente $\mathrm{z}$ leksikalnim pomenom »človekova zgornja okončina"v slovenskih (roka) in španskih (mano in brazo) frazeoloških enotah. Ker je univerzalnost človeškega telesa kot zunajjezikovne realnosti razmeroma velika, poleg tega pa je pri primerjavi gradiva obeh jezikov kot povezovalno prvino treba upoštevati tudi skupni civilizacijsko-kulturni okvir (evropskost, krščanstvo), je bila razmeroma velika ekvivalenca pričakovana. Kljub temu je analiza pokazala nekaj nezanemarljivih razlik na konceptualni, pomenski in površinski (oblikovni, izrazni) ravni. O roki kot metonimski osnovi v glagolskih in prislovnih stalnih besednih zvezah $\mathrm{v}$ španščini in portugalščini razmišlja tudi Elizabete Aparecida Marques.

Ostali prispevki obravnavajo zanimive teme s področja posameznih jezikov. Nader Al Jallad predstavlja jezikovno in kulturno študijo o velikodušnosti (al-karam) v arabščini. Kamila Tutaeva je avtorica jezikovno-kulturne študije o simbologiji medveda v ruski frazeologiji, Andrey Grigorev pa se ukvarja z zgodovino ruskih biblizmov. Katarina Kekić razpravlja o rasizmu in ksenofobiji v srbski frazeologiji, Dragana Mršević-Radović pa z zgodovinsko etimološkega vidika pristopa $\mathrm{k}$ analizi srbskih frazemov s komponentama duša in duh. Anna Idström opisuje metafore o lakoti v jeziku inari saami z vidika kognitivne teorije o metafori, Torben Arboe pa analizira frazeme jutlandskega (zahodnodanskega) dialekta. Saliha Iggui preučuje imena rastlin v berberski frazeologiji. Luis González García se ukvarja s frazeološkimi enotami v besedilih v španski sodobni glasbi. Študijo o portugalskih frazemih, povezanih s pijančevanjem in opijanjem, $\mathrm{z}$ vidika kognitivno analitične perspektive ikonskih modelov in metafor je prispevala Iovka B. Tchobanova. Kognitivni pristop pri analizi 
pojmov nasvet, razvada in slaba navada v španski frazeologiji razkriva Luis Luque Toro in poudarja pomen kognitivne semantike pri sistematizaciji frazemov, ki se nanašajo na omenjene pojme v španski kulturi. Marc Ruiz-Zorilla Cruzate prikazuje, kako lahko semantično strukturni modeli ruskega frazeologa Mokienka postanejo primerna orodja za verodostojno tolmačenje etimologije nekaterih španskih frazemov kot npr. a la chita callando. Juan de Dios Luque Durán zaključuje monografijo z zanimivim člankom o španskih frazemih, izhajajočih iz sveta bikoborb, ki so v evropski španščini zelo pogosti. Gre za kulturni okvir, ki z metaforičnimi asociacijami Špancem omogoča konceptualizacijo različnih dogodkov, situacij in čustev v vsakdanjem življenju. 